\title{
EL ESPECTADOR DEL NAUFRAGIO ANTROPOLÓGICAMENTE CONSIDERADO
}

\author{
ENVER TORREGROZA
}

Universidad del Rosario, Bogotá

\begin{abstract}
RESUMEN: La metafórica del «naufragio con espectador» contiene posibilidades hermenéuticas que van más allá de la comprensión del trasfondo inconceptualizable de la actitud teórica ante la existencia. También puede ser elaborada para dar cuenta de la frontera móvil entre el espacio de la seguridad y el espacio del riesgo, invitándonos a reconocer en la praxis de descarga existencial, implicada en toda actividad contemplativa ante el horror, un trabajo oscilante de sobrevivencia antropológica, y no sólo la gesta heroica de aquellos que, manteniéndose al borde del abismo, se asoman temerariamente a su vórtice. La orilla desde la que se contempla el naufragio pronto deja de ser por ello la tierra firme que en principio parecía ser, y el hundimiento mismo, al perder parte de su coloración como situación límite, deviene en referente opaco de los largos rodeos por medio de los cuales diferimos el encuentro directo con su crudeza.
\end{abstract}

PALABRAS CLAVE: metaforología, antropología filosófica, Hans Blumenberg, naufragio con espectador.

\section{The Shipwreck's Spectator form an Anthropological Point of View}

ABSTRACT: The hermeneutic applicability of the metaphors-set implied in the paradigmatic "Shipwreck with Spectator» goes beyond the understanding of the non-conceptual background of theoretical attitude towards existence. The seafaring metaphor can be also used to explain the borderline between Secured Lands and Risk Spaces, inviting us to recognize the oscillating of any anthropological surviving work, implied in the existential praxis of contemplating any storm; not only the epic attitude of temerarious heroes who look inside the abysm, standing in their boundaries. The shore from we "watch" the show of the shipwreck is no more the Terra Firma that used to be. The sinking then becomes an opaque referent of the long detour of life that we do in order to dilate the crude face-to-face with the darkest sea's deeps.

KEY WORDS: metaphorology, philosophical anthropology, Hans Blumenberg, Shipwreck with Spectator.

El presente ensayo tiene como propósito explorar algunas posibilidades hermenéuticas abiertas por la metafórica del naufragio con espectador ${ }^{1}$. La formulación más conocida de esta metafórica la encontramos en el proemio al libro segundo de la obra de Lucrecio De rerum natura, en la que se dibuja al sabio

1 Una primera versión de este trabajo fue leída el 19 de octubre de 2012 en el «Seminario de Epistemología Histórica e Historia de las Emociones» en el Centro de Ciencias Humanas y Sociales (CCHS) del Consejo Superior de Investigaciones Científicas (CSIC) de Madrid. Agradezco al profesor Javier Moscoso del Instituto de Filosofía del CSIC su amable invitación a participar en su seminario y los comentarios críticos a mi ponencia. También agradezco a los profesores Diana Victoria Carvajal Arroyave y Tomás Felipe Molina Peláez, jóvenes investigadores del Centro de Estudios Políticos e Internacionales de la Universidad del Rosario en Bogotá sus valiosas críticas, comentarios y aportes a este trabajo. 
como aquel que asume la posición de un espectador imperturbable ${ }^{2}$ que desde la seguridad de la orilla contempla el naufragio de otro hombre ${ }^{3}$. Se trata de una imagen potente para la comprensión de una variedad considerable de problemáticas filosóficas: desde la cuestión de las implicaciones prácticas de la actitud teórica, pasando por las condiciones de posibilidad de ciertas emociones estéticas, hasta la valoración moral de la actitud de cualquier observador ante una tragedia. Al mismo tiempo, es una imagen dúctil que admite variaciones en función de necesidades y expectativas de comprensión distintas. Su plasticidad está, por decirlo así, «virtualmente» contenida en la constante icónica «naufragio-espectador», a modo de una serie de posibilidades de configuración significativa de una escena. Tales posibilidades sólo se despertarían en la recepción de la imagen de base (Jauss 136) esto es, en las operaciones configuradoras de aquellos que utilizan el recurso de una metáfora heredada para interpretar una experiencia del tiempo presente que escapa a nuestras posibilidades de conceptualización.

Ya en su ensayo titulado precisamente Naufragio con espectador, el filósofo de Lübeck Hans Blumenberg examinó con detenimiento varias metamorfosis de esta metafórica, considerándola en distintos escenarios de recepción histórica, para hacer así patente su potencialidad como paradigma de una metáfora de la existencia. A partir del ejemplo ofrecido por Blumenberg de una aproximación hermenéutico-deconstructiva a las problemáticas metafísicas humanas, cabe desplegar un proceder filosófico inspirado en su «metaforología» para comprender el poder antropológico de las metáforas. Esto implica subrayar el rendimiento vital o el impacto significativo para la sobrevivencia del sentido de lo humano que puede tener un recurso de fondo; por ejemplo, un recurso metafórico con el que se pueda configurar una imagen de determinada experiencia

2 Este espectador imperturbable necesariamente se ha separado del mundo. El sabio ha tenido que superar su preferencia natural por lo agradable y apunta en cambio hacia una total indiferencia que lo separa del resto de hombres. Pero la indiferencia no la logra por la indiferencia en sí, sino como un método de inmunizarse contra las heridas, contra los cambios, contra el dolor. El sabio imperturbable es en este sentido antropotécnico un estoico. Su versión radical aparece en Marco Aurelio cuando dice: «Sería ridículo y extraño asombrarse sobre algún acontecimiento de la vida». (Marco Aurelio XII, 13).

3 «Revolviendo los vientos las llanuras / del mar, es deleitable desde tierra / contemplar el trabajo grande de otro; / no porque dé contento y alegría / ver a otro trabajando, mas es grato / considerar los males que no tienes: / suave también es sin riesgo tuyo / mirar los grandes ejércitos de guerra / en batalla ordenados por los campos: / pero nada hay más grato que ser dueño / de los templos excelsos guarnecidos / por el saber tranquilo de los sabios, / desde do puedas distinguir a otros / y ver cómo confusos se extravían / y buscan el camino de la vida / vagabundos, debaten por nobleza, / se disputan la palma del ingenio / y de noche y de día no sosiegan / por oro amontonar y ser tiranos. / ¡Oh míseros humanos pensamientos! / ¡Oh pechos ciegos! ¡Entre qué tinieblas / y a qué peligros exponéis la vida, / tan rápida, tan tenue! ¿Por ventura / no oís el grito de la naturaleza, / que alejando del cuerpo los dolores, / de grata sensación el alma cerca, / librándola de miedo y de cuidado?» (Lucrecio 10-20). Además de Naufragio con espectador, comentarios de Hans Blumenberg de este pasaje se encuentran en: Trabajo sobre el mito (133), La inquietud que atraviesa el río (37-38), La risa de la muchacha Tracia (57). 
vital concreta, difícilmente apresable en una caracterización teórica. Se trata no solo de aprovechar epistémicamente un símbolo para la comprensión del sentido de aquellos conceptos que carecen de intuición, como diría Kant en su Crítica del Juicio (Kant 44-45), sino de examinar también el valor pragmáticoorientativo y la pregnancia significativa existencial de ciertas configuraciones de la metáfora, a la hora de activar posibilidades de sobrevivencia de modos de vida humanos.

Vale por ello comenzar indicando el marco general hermenéutico que sirve de telón de fondo o de escenografía, a partir de la cual se desarrollan a continuación unas consideraciones hermenéuticas sobre la metáfora del naufragio con espectador, tratándose de una imagen específica dentro del conjunto amplio y proteico de la metafórica náutica y su serie inagotable de usos filosóficos. Si se asume la existencia humana, en clave ontológica, como un ejercicio de navegación constante, esto es, como el despliegue de los aperos náuticos necesarios para mantener las posibilidades de lo humano a flote, es posible tomar distancia de la idea del ser humano como un hijo de la Tierra, que entiende su existencia limitada a un proceso de crecimiento y decadencia vital a partir de una semilla sembrada en suelo fértil. Una comprensión de la vida como ésta última podría limitarse a ver en el desarrollo de las ramas y las hojas un despliegue espontáneo que, en lo esencial, sirve de soporte para la floración y la fructificación y que, por ende, es mero medio de reproducción de las semillas de las generaciones futuras. Por ello, el punto de partida hermenéutico que aquí se propone no comprende la existencia humana apelando a otra metafórica del suelo, ya no "cultivadora» sino «constructiva» (Blumenberg, La inquietud 77-80), aquella que habla del proceso de construcción paulatina de edificaciones sobre el basamento consolidado por las generaciones previas, o incluso dispuesto sobre un suelo limpio tras borrar todo trabajo heredado para comenzar de nuevo. En esta comprensión metafórica, el propósito de la actividad es llegar más alto, en comparación con lo que hicieron nuestros antepasados, o producir realidades más sólidas. A diferencia de esta metafórica que presupone la tierra firme como el lugar adecuado para las tareas del hombre, propongo comprender metaforológicamente la existencia humana apelando a un paradigma de metafórica náutica, en el cual se pueden enmarcar metáforas específicas que dependen de ella, pues ésta admite en su seno muchas variaciones. Se trata de la imagen del hombre como ser navegante; una metáfora que no deja de ser paradójica, aunque en medio de un importante desplazamiento, algo de lo que Blumenberg ya ha dado cuenta así:

«El hombre conduce su vida y levanta sus instituciones sobre tierra firme. Sin embargo, prefiere concebir el movimiento de su existencia, en su conjunto, mediante la metafórica de la navegación arriesgada». (Naufragio 13)

Y más adelante, también en Naufragio con espectador añade:

«Ante todo, dos presupuestos determinan la carga significativa de la metafórica de la navegación y el naufragio: por una parte, el mar como límite natural del espacio de las empresas humanas y, por otra, su demonización como ámbito de lo imprevisible, de la anarquía, de la desorientación» (Naufragio 15). 
El punto de partida de Blumenberg es comprender la metáfora de la navegación a partir del juego de oposiciones contenido en ella, entre la seguridad y firmeza de la tierra y la inseguridad y liquidez del mar, por lo que la interpretación de la tradición metafórica resalta su aplicabilidad para juzgar negativamente toda empresa humana de navegación en el mar, entendida como un riesgo innecesario. Aunque mucho más adelante en su libro, hablando del reposicionamiento del espectador en la recepción moderna de la metáfora Blumenberg postula la hipótesis de la «acomodación náutica»: nautische Arrangement (Naufragio 90, Schiffbruch, 78), permitiendo vislumbrar en algunas de sus recepciones la posibilidad de que el espectador del naufragio sea un viajero en el agua y no alguien que observa desde la orilla inamovible, el aprovechamiento de la metáfora se mantiene atado al servicio antropológico que ha prestado tradicionalmente en sus metamorfosis y recepciones, sin impulsar abiertamente la posibilidad de que una metafórica de la navegación constante se abra paso y navegue libremente. Blumenberg permanece haciendo cabotaje. Yo quiero asumir el viaje en alta mar como punto de partida.

Semejante transformación de la metáfora implica también que no asumo la idea de la navegación bajo el esquema del viaje con puerto de llegada y punto de partida fijo, sino que apunto a una comprensión de nuestra circunstancia ontológica como un escenario de flotación permanente en medio del agua, sin principio reconocible en tierra y sin final en ella, siendo por ello la meta del ejercicio de navegación la flotabilidad, el mantenerse sobre el agua navegando, mas no el arribo a un paraíso futuro o prometido ni el regreso a un hogar verdadero, añorado ${ }^{4}$ y ahora perdido ${ }^{5}$. Tal comprensión implica una renuncia tanto a las posibilidades de superación definitiva de nuestra condición existencial náutica como a la representación de nuestra situación total como el resultado de una caída, un estar arrojados en medio del mar, al haber abandonado o

\footnotetext{
4 «El hombre nunca es blanco donde vibra la fecha clavada, sino aguda flecha en el viento», decía Nicolás Gómez Dávila (Textos I, 14).

5 El filósofo bogotano Nicolás Gómez Dávila escribió un poema en prosa que puede ayudar a entender este punto. «El navío hundía en las aguas su aguda proa. La blanca vela, hinchada, se deslizaba sobre el mar y los petreles giraban alrededor del mástil, abandonados a sus largas alas. Las costas de las islas comenzaron a confundirse con el mar y ya solamente sobre las más altas cimas se posaba el sol. Los acantilados resplandecieron por última vez y la noche se adueñó, soberana color de violeta, del mar silencioso. Sentado en la proa del navío, Ulises contemplaba las lentas estrellas, perdido en el cielo luminoso y puro. El griego mentiroso y sutil meditaba; sus pequeños ojos móviles acechaban las secas montañas de Ítaca, densas masas en las tinieblas de la noche. Mas Ulises temía que los dioses fuesen favorables a sus ruegos y que le tocase de nuevo gobernar a sus campesinos sucios y sus marineros hedientes a pescado y a sal marina. ¡Ah, divino boyero! ¡Cástor y Pólux!, qué fastidio regresar a este duro suelo, escuchar en las tardes el elogio de Ítaca, de sus mujeres y sus viñas. Ya mañana no seré sino el rey Ulises, nada; cuando hoy soy aún Ulises, aventurero y desgraciado, hombre que la felicidad huye, el que visita a los muertos y duerme con las diosas. Sobre estas aguas traicioneras todo se puede esperar, la vida, la muerte y mil Ulises nuevos.» (Notas 301, 302) En suma, lo valioso, lo interesante, es el viaje, no el punto de llegada. Para Ulises no hay paraíso o un hogar al que se llega: sólo hay un viaje.
} 
perdido una nave: pues esta última posibilidad, que ve en la existencia humana un naufragio, supone haber perdido el recurso de flotación originario que sí habría sido el adecuado para navegar o vivir; provocando sendas lamentaciones por una pérdida de la que seríamos o los directos culpables, o las víctimas de un proceso injusto, sin razón de ser o sin sentido. Frente a una interpretación así de nuestra circunstancia - y no en vano uso la expresión orteguiana, ya que el mismo Ortega hizo uso preciso de una metafórica náutica ${ }^{6}$ para caracterizar nuestro modo de ser concreto ya sea como arbitrariedad o como castigo, con la que se provocaría una comprensión ciertamente gnóstica ${ }^{7}$, en términos substanciales, de nuestra existencia—, propongo aquí una ontonáutica ${ }^{8}$ : una configuración descargada de todo puerto de salida y de llegada absolutos, que avala la posición del hombre, no como puesto o lugar en el cosmos, sino como navegante perenne que, con escasos recursos de flotación, se mantiene en tránsitos provisionales y nunca definitivos.

La imagen de trasfondo propuesta no pretende resolver de manera total nuestras necesidades de flotación, pues no sólo cabría eventualmente proponer otra metafórica para tal efecto, sino que la misma metafórica náutica es lo suficientemente dúctil como para que se aprovechen sus variaciones, dependiendo

6 Ver Ortega 62, 74. Véase además Marías 28.

7 Se trata de una compresión gnóstica por el dualismo absoluto entre el paraíso y el naufragio total y por la pérdida del paraíso, o del recurso de flotación. ¿Pero el gnóstico no explica también que existe un recurso de flotación llamado ascesis? Lo que ayuda al gnóstico a soportar el mundo físico (satánico) es la ascesis que lo acerca a Dios. Ni siquiera el gnóstico supone la pérdida de un recurso de flotación originario.

8 Ver Torregroza 69.

9 Esta ontonáutica puede además ser ilustrada por El Conde de Montecristo de Alejandro Dumas. Si se recuerda su trama, se verá que Edmundo Dantés empieza siendo un marinero que, justo antes de ser ascendido a capitán, es injustamente encarcelado. Sin embargo, en el tiempo de su encarcelamiento se fija una meta: vengarse de aquellos que lo acusaron y encarcelaron injustamente. Finalmente, después de su escape vuelve a navegar y llega al lugar de su venganza. El problema es que cuando la alcanza, se da cuenta, como el Ulises de Gómez Dávila, de que el punto de llegada en realidad no es tal, de manera que su única opción es seguir buscando, seguir navegando. Recuérdense las líneas finales de El Conde:

«¿Dónde está el conde, amigo? Conducidme a él.

Jacobo extendió la mano y señaló en dirección al horizonte.

—Cómo! ¿Qué queréis decir? —-preguntó Valentina—. ¿Dónde está el conde? ¿Dónde está Haydée?

—Mirad —dijo Jacobo.

Los ojos de los dos jóvenes se fijaron en la línea indicada por el marino, y sobre ella, en el horizonte que separa el cielo del mar, distinguieron una vela blanca, grande como el ala de la gaviota.

— ¡Partió! —exclamó Morrel—, ¡partió! ¡Adiós, amigo mío! ¡Adiós, padre mío!

— ¡Partió! —murmuró Valentina-. ¡Adiós, amiga mía! ¡Adiós, hermana mía!

— ¿Quién sabe si algún día le volveremos a ver! — dijo Morrel, enjugándose una lágrima.

—Cariño — repuso Valentina-, ¿no acaba de decirnos que la sabiduría humana se encierra toda ella en estas dos palabras?:

¡Confiar y esperar!» (Dumas 696). 
de su funcionalidad, para la sobrevivencia antropológica. Sólo que aquí la uso, más allá de sus posibilidades significativas no domeñables por ningún discurso, con el fin de proponer una valoración específica de un modo de ser existencial (que agruparía a su vez una amplia pluralidad de modos de ser humanos divergentes entre sí); modo de ser en el que el reto humano de autoconfigurarse, de hacerse a sí mismo unos recursos de flotación o unas naves con las olas para sobrevivir, no implica asumir la flotabilidad como una empresa heroica, trágica y arriesgada, sino como una tarea diaria y prosaica de elaboración de sentido a nuestra escala y según nuestras posibilidades. La tarea de no hundirse hoy no puede, según esto, ser juzgada a partir de las expectativas de quien ve en la navegación un viaje hacia un lugar en el que no existiría la necesidad de mover los brazos para remar o nadar. Esto es así incluso cuando debemos simular una seguridad terrestre en nuestro tránsito inconstante, pues, como dice Nicolás Gómez Dávila: «Aun sabiendo que todo perece, debemos construir en granito nuestras moradas de una noche» (Nuevos escolios, 161, 4). Teniendo presente este marco general hermenéutico, consideremos ahora cómo puede funcionar a partir de allí la metáfora del naufragio con espectador, haciendo énfasis, como lo hace Blumenberg, en la figura del espectador del naufragio, con el fin de identificar las condiciones de posibilidad de su posición y las funciones que puede cumplir en el reparto de papeles de la escena dibujada en la metáfora.

Lo primero que hay que considerar es el problema del límite entre el espectador y el naufragio, la frontera movediza que los separa y que, en la imagen de Lucrecio, supuestamente es firme, ya que señala posiciones que no pueden intercambiarse: el espacio de la orilla firme, no sometido a los vaivenes de la fortuna, y el lugar del naufragio, donde atrevidamente los hombres navegan con la poca protección de unos recursos escasos. Un contraste así puede pretender mantenerse incluso en variaciones de la metáfora en las que el espectador no se encuentra en tierra firme, sino que es él mismo el lugar de lo inamovible, de lo que no se deja perturbar: una idea que no está sólo implicada en la escenificación propuesta por el atomista, sino que puede encontrarse en elaboraciones escépticas, estoicas o intempestivas de la situación del hombre. Blumenberg pone un par de ejemplos y yo añadiré uno más.

El primero de ellos es la interpretación que formula Montaigne de la leyenda trasmitida por Diógenes Laercio de las enseñanzas del socrático Antístenes en caso de naufragio. Para el antiguo hay que llevar consigo solo lo estrictamente necesario, aquello que «incluso un náufrago podría llevar consigo a nado» ${ }^{10}$ (Naufragio 23). Siguiendo esta idea, para el francés, el que se salva del naufragio de la existencia es aquel que se posee a sí mismo, quien se ha autodevelado y apropiado; «mucho antes - dice Blumenberg — de despojarse de la seguridad de su propia relación con el mundo, la antropología escéptica ha establecido

10 Y eso fue precisamente lo que hizo Diógenes de Sínope, discípulo de Antístenes, cuando fue capturado por piratas: llevó consigo lo único que podía llevar: su sabiduría. (Diógenes 173). 
para sí qué puede aceptar como sustancia inmune a peligros y pérdidas» (Naufragio 23) Como una suerte de viga incólume, el sobreviviente de Montaigne pareciera poder enfrentar las tempestades que lo acosan sin afectarse. Una idea que no deja de tener ecos de heroísmo ficticio, pues míticamente hablando, la única forma de soportar el canto de sirenas es apelando a unos recursos: cera de abejas, un lazo y unos marinos que te aten (Homero XII, 36-200). De la misma forma el encuentro directo con lo terrible no es posible, pues para encarar a Medusa hay que hacer uso de un espejo (Pseudo-Apolodoro 2.4.2). Que los recursos aquí empleados para enfrentar potencias en sí mismas indomables sean prosaicos no lo considero casual.

El segundo ejemplo de Blumenberg es el de Nietzsche, cuyo nombre ya evoca de por sí una vocación de nihilismo heroico de la cual él no habría sido la única víctima. Nietzsche habría sido uno de los testigos y de los responsables - espectador y náufrago a la vez- del giro característicamente moderno de la metafórica náutica, con el cual el mar se convirtió en espacio primero de aventura y exploración, de renovación y apertura a nuevos mundos, hasta que tardíamente devino en espacio apropiado por el hombre, objeto de conquista y explotación, pero también de integración (y no sólo comercial) de la aldea global - un tema, el del papel del mar en la configuración de la modernidad y nuestra relación con el espacio, que ya desarrolló Carl Schmitt en Tierra y mar, desprendiendo de allí sus tesis sobre la transformación del nomos de la tierra en el mundo moderno-. La fórmula de lo que Blumenberg denomina «acomodación náutica» ya está en Pascal, cuando justamente exponiendo el tema de la apuesta constata nuestra condición permanente de navegantes: ... vous êtes embarqué (Pascal 233) (Naufragio 28). De modo análogo a Pascal, que aprovecha esta condición para impulsar y darle fuerza a la necesidad de la apuesta infinita, ya que estando en el agua sólo cabría esta salida como alternativa al inevitable naufragio, Nietzsche la utiliza para impulsar la navegación intempestiva que debe acometer el filósofo en La gaya ciencia. (Nietzsche 116) Sólo que en el llamado de Nietzsche a desprenderse de todo puerto, soltar las amarras y aceptar que ya estamos en el agua, se conserva un aire de infinitud y un tono de heroísmo romántico, que no siendo incompatible con el tono de su pensamiento, sí se distancia de la posibilidad, de cara a Blumenberg y que aquí defiendo, de una mera apuesta por la autoconservación prosaica. Nietzsche no tuvo ningún reparo en apostarle incluso a la imagen de una viga de la que agarrarse en caso de naufragio y que se sostendría valerosamente en medio de la debacle (Naufragio 30). Si bien, el recurso de Nietzsche a la viga sólo supone el trasfondo del naufragio, sin considerarlo explícitamente, y teniendo en cuenta que su aproximación convierte el problema en un asunto de «instrumentos de autoconservación» (en la expresión de Blumenberg) (Naufragio 30), se trata de una forma de renunciar a lo que cotidianamente nos permite flotar: la carcasa artificial y vieja de nuestras naves, asumiendo que es un estorbo para una navegación más pura.

El tercer ejemplo que quiero mencionar del contraste entre la firmeza y la inseguridad está en la imagen del escéptico Pirrón, que montado en un barco 
en medio de la tempestad, y en contraste con la conducta desesperada de los otros tripulantes, se limita a señalar con el dedo a un puerquito que come tranquilamente del piso de la cubierta indiferente a lo que está pasando, como ejemplo de la tranquilidad de ánimo del sabio frente a un naufragio ${ }^{11}$. Una imagen iluminada en una miniatura del Petrarca-Meister en el siglo XvI (Imagen 1) y que había recogido Diógenes Laercio siguiendo la noticia de Posidonio (Diógenes 9,11 [68]).

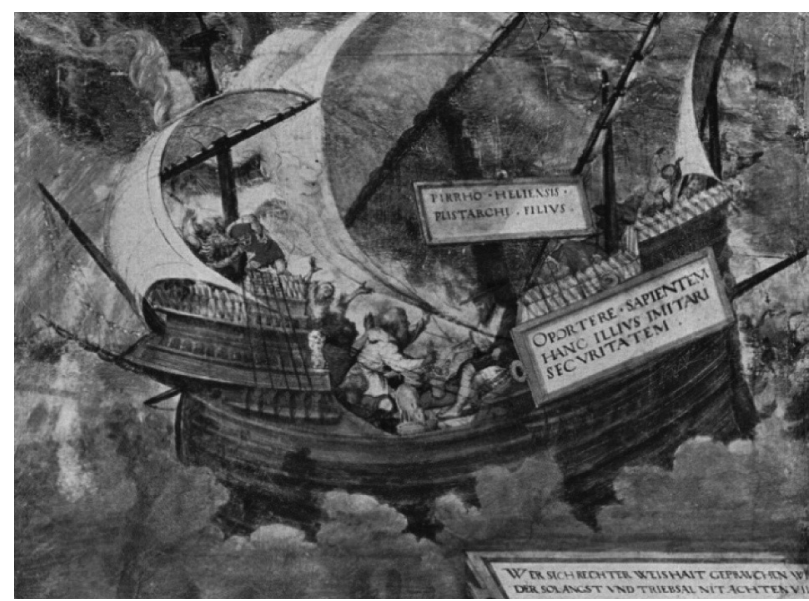

Imagen 1. "El filósofo Pirrón en un mar tempestuoso». Miniatura del Petrarca-Meister, S. XVI. Alte Pinakothek, Múnich.

Sea que el espectador se encuentre o no en la orilla, las tres imágenes propuestas recalcan la posibilidad de una firmeza irrebatible que contrasta radicalmente con el remolino desordenado que le rodea. Pero se trata de una forma de trazar el límite entre espectador y naufragio que pretende olvidar la movilidad de semejante frontera siempre corrediza; al mismo tiempo que puede resultar, en su inflexibilidad, poco funcional cuando se trata de sobrevivencia antropológica. Pues siendo espectador también hay riesgo de ahogo.

El mismo proceso de autoconfiguración humana requiere como trasfondo un espacio de imposibilidad — esto es, de inhumanidad- como condición de posibilidad de la tarea diaria de elaborar mundos significativos. Sólo bajo un esquema así dualista, que contrapone el espectador con el naufragio, sin substancializar-reificar los papeles de la escena dibujada, se puede funcionalmente

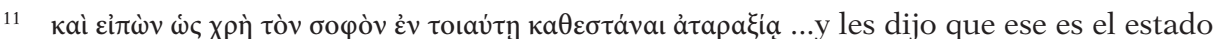
imperturbable - ataraxia - que un hombre sabio debe tener (Traducción libre) (Diógenes 9, $11[68])$. 
caracterizar la circunstancia del hombre, en la medida que el modo de ser humano lo interpretemos como una conquista diaria del hogar, que cada mañana debemos hacer de nuevo. En este sentido la metáfora del naufragio con espectador nos remite a una comprensión funcionalmente gnóstica $-\mathrm{y}$ no sustancialmente gnóstica - de la problematicidad ontológica del hombre y sus posibilidades de autoconfiguración. El espectador del naufragio resulta ser, en este escenario, un papel que puede implicar diferentes modos de ser frente a la frontera misma que lo separa del naufragio, siendo en todos los casos imagen del sobreviviente. Por lo que hay que pensar no tanto si el naufragio es en sí mismo soportable, si no qué tanto podemos soportar nuestra condición de espectadores, tanto prácticamente (moral y políticamente hablando), como sensiblemente (epistémica y estéticamente hablando). Pues antropológicamente considerado, ser espectador (del naufragio) es metáfora de lo que podemos hacer diariamente para ser humanos.

Una variación significativa de la oposición funcionalmente gnóstica sobre la que se ancla el rendimiento de la metáfora opera en la ontonáutica que propongo: en vez de considerar la tarea de navegación como un llegar a destino, siendo el navegar un apuro por llegar pronto a casa, podemos entender nuestros empeños antropológicos contemporáneos como la necesidad de mantenernos a flote - en la línea de flotación-, sobre la superficie, lidiando diariamente con el océano y sus profundidades, siendo éste el trasfondo que sirve de condición de posibilidad «cuasitrascendental» de nuestros procesos de autoconfiguración. Esta comprensión «vertical» y no «horizontal» de la navegación, que tiene como efecto justamente aprender a valorar el mantenernos horizontalmente en el agua, implica comprender la frontera móvil entre naufragio y espectador como una línea de flotación. Se trata de una móvil línea que oscila con las olas y que nos indica que hay algo que siempre debe permanecer bajo el agua, aunque nunca en el fondo total de las cosas, para que haya algo que sobreviva y respire por encima de ella. El mayor riesgo es el hundimiento total y definitivo - de nuevo, un naufragio pleno y consumado- que implicaría justamente tocar fondo; llegar, ahí sí, a un piso firme, que sólo ocurre en las indomables profundidades oceánicas y que, en esta variación, se ha convertido en algo intolerable e indeseable.

Examinemos dónde pueden ocurrir estos escenarios funcionalmente contrapuestos en los que la línea de flotación es porosa y, por tanto, debe mantenerse todos los días con tareas de navegación, remando o agitando los brazos - si es que quedamos reducidos a nuestra condición natatoria, como diría Julián Marías, leyendo a Ortega (Ortega 62, 74) (Marías 28)—.

Lo primero es no desplazar las potencias indomables del abismo marino a la interioridad humana. Algo que ya Jung advirtió en Psicología y religión, sugiriendo la enorme sobrecarga que puede representar para nuestras necesidades de flotación el asumir que los demonios son realidades inconscientes que habitan al interior de la subjetividad humana (Jung 133), siendo que nuestra tarea debe ser exteriorizarlas, exorcizarlas o descargarlas en una proyección mítica útil con la que podamos realmente lidiar en el transcurso de un día o en 
el tránsito onírico de una noche. Siendo día y noche las crestas de las olas en las que oscilamos.

Los límites del espectador como un yo, sea en correspondencia con la imagen del individuo o ya sea apelando a una subjetividad colectiva, son por supuesto elaboraciones móviles relativamente funcionales y deconstruibles que hay que asumir flexiblemente, desconfiando al mismo tiempo de la posibilidad de una "consciencia plena» que, como piloto racional y firme de una nave, pretende domeñar no sólo unas naves que no son suyas ni obra suya, sino también las corrientes, el océano profundo, los vientos y hasta las estrellas que giran en el firmamento. El piloto que se cree dueño de los elementos como mástil imperturbable ante el embate de las olas, bastándose a sí mismo para ser, hay que considerarlo más o menos como una poco funcional ilusión antropológica. Jung lo afirma así:

En verdad la psique es madre, sujeto y posibilidad de la consciencia misma. Trasciende ampliamente los límites de la consciencia, siendo así lícito comparar ésta con una isla en el océano. Al paso que la isla es pequeña y estrecha, el océano es infinitamente ancho y profundo y encierra una vida que sobrepasa en todos los aspectos la vida isleña, tanto en su índole cuanto en su extensión. Cabría objetar a esta imagen el no haber aducido prueba alguna de que la conciencia no tenga más importancia que la asignada a una pequeña isla en medio del océano. Mas por cierto tal demostración es de por sí imposible, pues frente a la conocida extensión de la conciencia, se yergue la desconocida «extensión» de lo inconsciente, a cuyo respecto en rigor sólo sabemos que existe y que, en virtud de su existencia opera sobre la conciencia y su libertad en un sentido restrictivo. Donde quiera señoree lo inconsciente se da también falta de libertad e incluso obsesión. La amplitud oceánica no es al fin sino un símil de la capacidad de lo inconsciente de limitar y amenazar la consciencia. [...] A la moderna hipertrofia de la conciencia débese, precisamente, su mencionada hybris, y el hecho de que los hombres no reparen en esa peligrosa autonomía de lo inconsciente. El supuesto de la existencia de dioses o demonios invisibles constituye una formulación de lo inconsciente psicológicamente mucho más adecuada, aún cuando se trata de una proyección antropomórfica. Pues bien, como el desarrollo de la conciencia exige la renuncia de todas las proyecciones asequibles, tampoco es posible seguir sosteniendo ninguna mitología en el sentido de una existencia no psicológica. Si el proceso histórico de «des-animación» del mundo, o lo que es lo mismo, si el retiro de las proyecciones, continua progresando como hasta el presente, todo cuanto se halle afuera, sea de carácter divino o demoníaco, habrá de volver al alma, al interior desconocido del hombre, de donde aparentemente partió (Jung 136-138)

El ser humano diariamente se configura sobre un mar insondable, sin concretarse su tarea en una sola y única forma estable e invariable (algo así como un "yo» substancial, por ejemplo), puesto que todas sus elaboraciones no son más que los rastros que deja la nave en su trasegar oceánico; unos cursos que temporalmente dejan huella, pero que luego se borran si nadie vuelve a cruzarlos. Ser humanos no es una tarea ya consumada sino que su ser está 
en obra -work in progress-. Dicho en clave heideggeriana y derridiana: es un acontecimiento, el acontecimiento de navegar oscilante entre lo humano y lo inhumano, por lo que el espectador y el naufragio es la línea de flotación que los separa y los une, haciéndolos posibles y, también, imposibles. Quien es espectador de su naufragio trabaja en impedir el naufragio del espectador, no siendo tan meramente pasiva su labor, como la idea de «contemplación» nos haría pensar. Así como en esa otra potente metafórica, la del mito de la caverna, el hombre no está sino en el tránsito de ida y vuelta a ella, de entrada y salida de la misma, ser humano es mantener la línea de flotación compensando cargas y descargas, dejando que nos hundamos un poco para no hundirnos plenamente, sin pretender nunca tener las armas para enfrentar los demonios marinos de fondo, solos, sin aire y sin recursos.

La línea de flotación también puede considerarse porosa no solamente porque no es posible establecer con plena seguridad cuándo estamos más acá o más allá de la línea, cuando hemos trazado por ejemplo la frontera entre el concepto y la metáfora o entre el logos y el mythos (Blumenberg, Trabajo sobre el mito cap. 1). Lo que implica antropológicamente que la frontera de lo humano siempre está en juego y que el movimiento de lo humano no sólo está en ser espectador, sino también en naufragar un poco.

Algo así podría estar implicado en el riesgo asumido por quien pretende ser espectador del naufragio con el estilo de quien permanece sistemáticamente en la línea, provocándola, forzándola hasta el absurdo o cruzándola temerariamente para con ello salir definitivamente avante, con la expectativa de quien cree vencer los problemas si se mete a fondo en ellos. Ejemplos de ello, no sólo desplegados filosóficamente — esto es, con una supuesta neutralidad frente a los asuntos del mundo-, sería la vocación de profundidad, de ontología de fondo del «mirar a la metafísica a la cara» de Heidegger — de quien Sloterdijk ya dijo que era una suerte de buzo de profundidad (Extrañamiento 80)_, o el nihilismo heroico de Jünger que no le bastaba permanecer a este lado de la línea, sino que debió y quiso cruzarla hasta llevarla a sus más irreconciliables extremos pretendiendo quizá así hacerla estallar-(Volpi 108; Jünger, El Trabajador 58). No estoy pensando sólo en el debate filosófico que con el título «Sobre la línea» puso a Jünger y a Heidegger a competir por quién habría asumido más lejos el acto hiperbólico de estirpe nietzscheana de poner a prueba los límites de la significatividad de nuestro presente, atravesando con ímpetu el desierto del sin sentido, sino también en el relato, entre heroico y prosaico, que el joven Jünger nos ofreció de su participación como soldado del ejército alemán en el frente durante el combate de trincheras en la Primera Guerra Mundial (Tempestades de Acero). Siendo valiente espectador y náufrago a la vez, el joven soldado, que tenía tiempo para garrapatear sus experiencias en una libreta metido en el barro de la línea del frente, no dudaba en atreverse a cruzar en las noches la tierra de nadie que separaba las alambradas de los ejércitos enemigos, yendo hasta el borde, como nos relata en Tempestades de acero. Se trata de un modo de ser espectador poco cotidiano y común como para ser compartido por los demás, aunque nunca hay que olvidar que en esa empresa de sobreviviencia 
diaria, el soldado Jünger llevaba sus modestos aperos de soldado, su prosaica ración de comida que combinaba con su prosaica elaboración en prosa de sus cotidianas experiencias en la guerra retardada de trincheras, siendo el casco un instrumento de flotación que salvó su cabeza más de una vez.

Para ser un espectador de los naufragios contemporáneos no es necesario arriesgar temerariamente el pellejo, ni haber sido un espectador que, más que sobreviviente —como el sobreviniente del siglo que fue Jünger-, resultó ser náufrago de su contemplación. Este último caso habría sido el del piloto norteamericano Claude Eatherly, que el 6 de agosto de 1945 eligió el blanco sobre el cual, instantes después, el bombardero B-29 Superfortress, apodado «Enola Gay», y piloteado por Paul Tibbets, lanzó la bomba atómica («Little Boy») sobre la ciudad de Hiroshima. La correspondencia entre Eatherly y Günter Anders que ha sido publicada, resulta ser una muestra de las dificultades de sobreviviencia de quien siendo espectador activo de un naufragio termina arrastrado por la onda explosiva que deja tras de sí12; algo que le puede ocurrir a quien contemple, incluso con relativa fascinación, el rastro de la explosión, bajo la forma de una huella fotográfica en la que el espectador presiente su impotencia frente al horror; todo lo opuesto al espectador de Lucrecio.

¿Podemos contemporáneamente lidiar con los horrores y ser capaces no sólo de no dejarnos arrastrar por el torbellino abismal de las potencias abisales desatadas en nuestros tiempos, sino también de soportar el privilegio antropológico de ser espectadores? Todo depende de que valoremos, creo, nuestras posibilidades de elaboración prosaica. En el libro Ante el dolor de los demás (Regarding the Pain of Others) de 2003, Susan Sontag ha ofrecido una aproximación a la experiencia del dolor ajeno en imágenes pictóricas y fotográficas, en el marco de la cual comenta la reacción de espectadores cercanos a la experiencia de los atentados a las Torres Gemelas de Word Trade Center en la ciudad de Nueva York el 11 de septiembre de 2001. A los asistentes inmediatos de un naufragio televisado, les pareció, incluso viéndolo a simple vista, una suerte de proyección onírica o una película de cine. Sontag acusa a la cultura moderna de construir una relación mediada con la realidad que preconfigura nuestro modo de reaccionar ante el dolor de los demás, desplegando la gente del común suplantaciones fantásticas que cancelarían el peso profundo de un hundimiento grave (Sontag 14). ¿Pero quién no se descarga para no hundirse? Vivir como una suerte de ensoñación la experiencia de la tragedia está

12 Anders le dice a Eatherly, en su primera carta del 3 de junio de 1959 esto: «Usted tiene la desgracia de haber dejado detrás de sí 200.000 muertos. ¿Y cómo iba a ser posible sentir dolor por la muerte de 200.000 personas? ¿Cómo iba a ser posible lamentar algo semejante? No sólo usted es incapaz de hacerlo, nosotros tampoco podemos, nadie puede hacerlo. Por más que lo intentemos, aquí el dolor y el arrepentimiento son impotentes. Así pues, Eatherly, usted no tiene la culpa de que sus esfuerzos sean inútiles. Esta inutilidad es consecuencia de lo que anteriormente he denominado el carácter radicalmente nuevo de nuestra situación, a saber: el hecho de que, en cierto modo, podemos producir más de lo que somos capaces de representar.» (Anders 36) 
antropológicamente justificado como una posibilidad prosaica y cotidiana de poder atravesar tempestades de las que no necesariamente se sale incólume, como una suerte de recurso de navegación que nos permite flotar a pesar de saber que nos estamos hundiendo. Somos también, antropológicamente considerados, televidentes, y lo prosaico que hay en ello es lo humano que hay en ello, en las posibilidades de lidiar indirectamente con lo que no podemos tratar directamente, en las formas de representar lo irrepresentable. Pedirle más a un ser humano quizás es demasiado ${ }^{13}$.

\section{REFERENCIAS BIBLIOGRÁFICAS}

Anders, G., El piloto de Hiroshima: más allá de los límites de la conciencia, correspondencia entre Claude Eatherly y Günter Anders. Trad.Vicente Gómez Ibáñez. Barcelona: Paidós, 2010.

Blumenberg, H., La inquietud que atraviesa el río. Un ensayo sobre la metáfora. Trad. Jorge Vigil. Barcelona: Península, 1992. [Die Sorge geht über den Fluß. Fráncfort: Suhrkamp, 1987.]

- La risa de la muchacha tracia. Una protohistoria de la teoria. Trad. Teresa Rocha e Isidoro Reguera Pérez. Valencia: Pretextos, 2000. [Das Lachen der Thrakerin. Eine Urgeschichte der Theorie. Fráncfort: Suhrkamp, 1987.]

- Naufragio con espectador: Paradigma de una Metáfora de la Existencia. Trad. José Vigil. Madrid: Visor, 1995. [Schiffbruch mit Zuschauer: Paradigma einer Daseinsmetapher. Fránkfort: Suhrkamp, 1979.]

- Trabajo sobre el mito. Trad. Pedro Madrigal. Barcelona: Paidós, 2003. [Arbeit am Mythos. Fráncfort: Suhrkamp, 1979.]

Diógenes, L., Vidas, opiniones y sentencias de los filósofos más ilustres. Trad. José Ortiz y Sanz. Dos volúmenes. Buenos Aires: Emecé, 1945.

Dumas, A., El Conde de Montecristo. 1844. Grupo Anaya. 2006

Gómez Dávila, N., Notas. Bogotá: Villegas, 2003.

- Nuevos escolios a un texto implícito II. 1986. Bogotá: Villegas, 2002.

- Textos I. 1959. Bogotá: Villegas, 2002.

Homero. Odisea. Trad. José Manuel Pabón. Madrid: Gredos, 2000.

13 De hecho, según Sloterdijk el hombre moderno exige su derecho a la anestesia; es decir, a formas de atravesar las tempestades sin sentirlas. Nos dice en Has de cambiar tu vida: «Desde el punto de vista filosófico, la reintroducción de la anestesia total marcaría una cisura en las relaciones del hombre moderno consigo mismo. Y esto no sólo es así porque ya no hay forma de entender la posición del sujeto contemporáneo respecto a su naturaleza y a su operabilidad mientras no se tenga en cuenta la nueva posibilidad de que acepte la interrupción de su sensibilidad al dolor. Dado que con esto frecuentemente queda en suspenso su estado de conciencia, el sujeto se ve confrontado con la dramática elección de retirarse momentáneamente de su ser-para-sí, trasladándose totalmente a la posición de un ser-en-sí inconsciente. Y no sólo está de acuerdo con que le hieran en su propio interés — cosa que se presupone cuando se deja operar-, sino que asume además como ventajoso su desvanecimiento artificial. Este hecho es digno de consideración, ya que con él se establece explícitamente una tesis que hasta entonces hubiera resultado inconcebible: ya no hay que exigir al hombre que se mantenga siempre en un estado de vigilancia.» (La cursiva es mía).(Has de cambiar 485) 
JAuss, H. R., Historia de la literatura como provocación. Trad. Juan Godo Costa y Jose Luis Gil. Barcelona: Península, 2000.

Jung, C. G., Psicología y religión. Trad. T. M. de Brugger. Barcelona: Paidós, 1991.

JÜNGER, E.: El trabajador. 1932. Barcelona: Tusquets, 1990.

- Tempestades de acero. 1920. Barcelona: Tusquets, 2005.

Kant, I., «Crítica del juicio». Obras Kant II. 1790. Maximiliano Hernández, editor. Madrid: Gredos, 2010.

LuCRECio, De la naturaleza de las cosas: poema en seis cantos. 1822. Miguel Castillo Bejarano, introducción y notas. Madrid: Alianza, 2003.

Marco Aurelio, Meditaciones. España: Alianza Editorial, 2012.

MARÍAs, J., «El primer libro de Ortega». En: Ortega y Gasset, J. Meditaciones del Quijote. Julián Marías, edición. Madrid: Cátedra, 1984.

Nietzsche, F., La ciencia jovial: La gaya scienza. 1882. Trad. José Jara. Caracas: Monte Avila, 1990.

Ortega y Gasset, J., Prólogo para alemanes. Domingo Hernández Sánchez, edición. Madrid: Tecnos, 2002.

2002.

Pascal, B., Pensamientos. 1669. Trad. Xavier Zubirí. Madrid: Alianza, 2004.

Pseudo-Apolodoro, Biblioteca mitológica. Julia García Moreno, introducción, traducción y notas. Madrid: Alianza, 1993.

SloterdiJK, P., Has de cambiar tu vida. 2009. España: Pre-textos, 2012.

- Extrañamiento del mundo. 1993. Eduardo Gil Vera, traducción y prólogo Valencia: Pretextos, 1998.

Sontag, S., Ante el dolor de los demás. Trad. de Aurelio Mayor. Madrid: Alfaguara, 2004.

Torregroza, E., La nave que somos: Hacia una filosofía del sentido del hombre. Bogotá: Pontificia Universidad Javeriana, 2014.

VolpI, F., El nihilismo. Trad. Cristina I. de Rosso y Alejandro G. Vigo. Buenos Aires: Biblos, 2005.

Universidad del Rosario

ENVER TORREGROZA

Bogotá

torregroza@gmail.com

[Artículo aprobado para publicación en noviembre de 2013] 